\title{
China and the WTO Dispute Settlement System
}

The Global Trade Lawyer and the State Capitalist

\section{Leïla Choukroune}

\section{(2) OpenEdition Journals}

Electronic version

URL: http://journals.openedition.org/chinaperspectives/5815

DOI: $10.4000 /$ chinaperspectives.5815

ISSN: 1996-4617

\section{Publisher}

Centre d'étude français sur la Chine contemporaine

\section{Printed version}

Date of publication: 30 March 2012

Number of pages: $49-57$

ISSN: 2070-3449

\section{Electronic reference}

Leilla Choukroune, "China and the WTO Dispute Settlement System », China Perspectives [Online], 2012/1 | 2012, Online since 30 March 2015, connection on 28 October 2019. URL : http:// journals.openedition.org/chinaperspectives/5815; DOI : 10.4000/chinaperspectives.5815 


\title{
China and the WTO Dispute
}

\section{Settlement System}

\author{
The Global Trade Lawyer and the State Capitalist
}

\section{LEÏLA CHOUKROUNE*}

\begin{abstract}
Since its accession to the WTO on 11 December 2001, China has been involved in eight cases as complainant, 23 as respondent, and 89 as a third party. Against all pre-entry predictions, the China-related cases have not overburdened the WT0 dispute settlement system, as if all parties were implicitly respecting a latent period before engaging in commercial hostilities. Often portrayed as a "passive rule taker" in the immediate aftermath of its accession, China was not only learning by attentively watching other members' strategies, but also benefiting from the benevolent attitude of its main trading partners, the US and the EU. Moreover, its participation in 89 WTO disputes as third party is not a trivial detail nor is it a sign of passivity, but rather one of cautious preparation that corresponded to the time needed to properly apprehend its new legal tools and all rights thereunder.

While there are many ways of approaching such an already vast body of decisions and related legal and economic literature, this article tries to reflect the uniqueness of the Chinese trade regime and the impact of such a peculiar mix between economic libreralisation and maintenance of the state on other WTO Members in addressing the following questions: the transitional product-specific safeguard measures adopted in reaction to a market disruption caused by Chinese imports, the antidumping and countervailing duties issue, and the restrictions on exportations or importations imposed by China for economic, but also societal and political reasons.
\end{abstract}

\section{KEYWORDS: China, WTO, Dispute Settlement, Safeguards, Dumping, Subsidies, Imports and Exports Restrictions.}

S ince its accession to the WTO on 11 December 2001, China has been involved in eight cases as complainant, 23 as respondent, and 89 as a third party. (1)

Against all pre-entry predictions, the China related cases have not overburdened the WTO dispute settlement system, as if all parties were implicitly respecting a latent period before engaging in commercial hostilities. Often portrayed as a "passive rule taker" (2) in the immediate aftermath of its accession, China was not only learning by attentively watching other members' strategies, but was also benefiting from the benevolent attitude of its main trading partners, the US and the EU. Moreover, its participation in 89 WTO disputes as third party is not a trivial detail, (3) nor is it a sign of passivity, but rather one of cautious preparation that corresponded to the time needed to properly apprehend its new legal tools and all rights there under. This strategic learning was rapidly evidenced by the novel official discourse on rights and obligations the Chinese leaders developed as a powerful tactical instrument. As early as January 2003, at the Dispute Settlement Body's special session, the Chinese delegation to the WTO presented a "communication" (4) aimed at the improvement of the "special and differential" provisions contained in the Dispute Settlement Understanding (DSU), the WTO rules governing the settlement of disputes. An ambiguous emerging super power, China was playing the developing country's card (5) in requesting a genuine special and differential (S\&D) treatment to be introduced in the DSU as it is in many other WTO legal instruments. ${ }^{(6)}$ Recalling its commitment to engage in WTO activities and "play a positive role in the formulation of multilateral trade rules, including rules concerning
Leilla Choukroune (Doctorate in International Law from Paris Sorbonne Law School, Lawyer Paris Bar) teaches international economic law at Maastricht University. She is Deputy Director of the Institute for Globalization and Economic Regulation (IGIR). Her research deals with the interactions between trade, investment, and human rights with a special interest for the emerging world and Asia, China, and India in particular, where she has lived and visits very frequently.

1. See Annex 1. The WTO Dispute Settlement Understanding (DSU), the rules governing the settlement of disputes at the WTO provides for two major ways of resolving disputes: consultation or negotiation and, if this first phase does not bring any outcome, adjudication by panels and the Appellate Body (arbitration and good offices, conciliation and mediation are also available but hardly been used). The DSU defines three categories of actors (all of them being exclusively WTO Members): the complainants, the respondents and the third parties. The role of third parties is not at all trivial. These WTO Members do influence the settlement process from the consultation phase to the adoption of a decision by a constituted panel. The article 10 para2 of the DSU states: "Any Member having a substantial interest in a matter before a panel and having notified its interest to the 'Dispute Settlement Body' (DSB, referred to in this Understanding as a "third party") shall have an opportunity to be heard by the panel and to make written submissions to the panel. These submissions shall also be given to the parties to the dispute and shall be reflected in the panel report." On third parties in WTO disputes, see, for instance, Marc L. Busch and Eric Reinhardt, "Three's a Crowd: Third Parties and the WTO Dispute Settlement," World Politics, vol. 58, April 2006, pp. 446-477.

2. See, for example, Henry Gao, "Taming the Dragon, China's Experience in the Dispute Settlement System," Legal Issues of Economic Integration, vol. 34, no. 4, 2007, pp. 369-392, and "China in the WTO Dispute Settlement System: From Passive Rule-Taker to Active Rule-Maker," in Ricardo Meléndez-Ortiz et al. (eds.), A Decade in the WTO, Implications for China and Global Trade Governance, ICTSD Programme on Global Economic Policy and Institutions, December 2011.

3. In reference to the key role of third parties, supra note 1.

4. See TN/DS/W/29, 22 January 2003, "Improving the Special and Differential Provisions in the Dispute Settlement Understanding," Communication of the Permanent Mission of the People's Republic of China.

5. China is indeed considered a developing country member. Interestingly, it has been a long tradition for the GATT Contracting Parties and the WTO Members to self-declare their status as developed or developing countries. 
dispute settlement mechanism," (7) China proposed the reinforcement of the S\&D treatment for developing countries and precisely the following key reforms:

(a) Developed-country Members shall exercise due restraint in cases against developing-country Members. For instance, developed-country Members shall not bring more than two cases to the WTO Dispute Settlement Body against a particular developing-country Member within a calendar year.

(b) Where a developed-country Member brings a case against a developing-country Member, if the final rulings of a panel or the Appellate Body show that a developing-country Member does not violate its obligations under the WTO Agreements, the legal costs of the developingcountry Member shall be borne by the developed-country Member initiating the dispute settlement proceedings.

(c) Developed-country Members shall help developing-country Members participate in the dispute settlement mechanism in a more effective way through providing technical assistance and capacity building programmes. ${ }^{(8)}$

As a Recently Acceded Member (RAM) and diligent student in international trade, China was testing other members' readiness to interpret its Protocol of Accession (9) and bring disputes as well as the available strategies to influence the flow and pace of these potential cases. An active learner and rules negotiator during the first seven years of its participation, Beijing progressively matured into a more offensive player while it brought 6 new cases as complainant between 2008 and today.

Chicken, tires, paper, steel, distribution rights, intellectual property, or solar panel, the China related disputes cover all possible areas of international trade ${ }^{(10)}$ and directly address the interpretation of China's unique Protocol of accession. But one also finds rapidly that the vast majority of cases - and cases to come - deal with anti-dumping measures adopted in reaction to what is often perceived, in Europe and the US, but also increasingly in the developing world, as unfair trade.

There are many ways of approaching an already vast body of decisions and related legal and economic literature. To better reflect the uniqueness of the Chinese trade regime and the impact of such a peculiar mix between economic liberalisation and maintenance of the state on other WTO members, I have chosen to focus on three singular aspects now emerging from the settled disputes: the transitional product specific safeguard measures adopted in reaction to a market disruption caused by Chinese imports, the antidumping and countervailing duties issue, and the restrictions on exports or imports imposed by China for economic, but also societal and political reasons.

\section{Transitional product safeguard measures and China's protocol of accession interpretation}

\section{WTO-plus and WTO-minus rights and obligations}

China's Protocol of Accession to the WTO was and remains unique in that it includes a number of special or WTO-plus commitments as well as WTOminus rights. ${ }^{(11)}$ Like all other new Members to the WTO, China has undertaken a series of traditional WTO commitments on market access and rules. Unlike other accessions, however, China has not only accepted extensive market access commitments, but also a number of specific rules that are now largely criticised by its officials and trade experts. ${ }^{(12)}$ The WTO-plus commitments impose stricter disciplines than generally required by the WTO agreement, while the WTO-minus provisions allow other WTO members to take protective measures against Chinese exports that deviate from general WTO disciplines. Lastly, China's Protocol of Accession prevents China from seeking S\&D treatment in the same way as other developing countries members.

\section{The WTO-plus commitments include the following elements:}

1. "Rule of Law" obligations related to the establishment of a more transparent trade regime as well as the judicial review and uniform administration of trade. Adopted in relation to article X of GATT 94 (Publication and Administration of Trade Regulations), these provisions remain a major obstacle to the genuine application of China's WTO commitments. ${ }^{(13)}$

2. Obligation to progressively practice a market economy. While WTO rules assume a market economy, nothing in the Agreement prescribes the participation of non-market economies (NME). China's Protocol of Accession, in contrast to what is (not) imposed on other members, establishes special market economy obligations for China. Beijing is indeed obliged to allow the market to determine prices for a number of domestic goods and is prohibited from using price controls except for specifically listed categories of products. ${ }^{(14)}$ Moreover, China should liberalise foreign trading rights and not influence the decisions of State

6. The "Special and Differential Treatment" granted to the WTO developing Members finds its roots in the Preamble of the WTO Agreement with the "need for positive efforts designed to ensure that developing counties [...] secure a share in the growth in international trade commensurate with the needs of their economic development." The special and differential treatment provisions can take many forms (safeguards, flexibility, transitional periods, protection of infant industry, etc) and have to be explained agreement by agreement. See generally the work of the WTO Trade and Development Committee, www.wto.org/english/tratop_e/devel_e/dev_special_differential_ provisions e.htm (consulted on 25 February 2012); and for an excellent synthesis of the main components of this treatment, Peter van den Bossche, The Law and Policy of the World Trade Organisation, (second edition), Cambridge, Cambridge University Press, 2008, pp. 723-730.

7. See TN/DS/W/29, 22 January 2003, art. cit.

8. Ibid. p. 1. The Doha Ministerial Declaration mandates negotiations on improvements and clarifications of the DSU. The Chinese proposal aimed at this objective. The Doha negotiation cycle having not been concluded, these proposals could not be furthered. See www.wto.org/english/ tratop_e/dda_e/dohasubjects_e.htm (consulted on 25 February 2012).

9. According to its Protocol of accession to the WTO, China cannot benefit from the special and differential treatment as other developing countries members. See Protocol of Accession of the Republic of China to the WTO (WT/L/432), 10 November 2001, and the incorporated paragraphs of its Working Party Report (WT/ACC/CHN/49).

10. See Annex 1:WTO Disputes Cases involving China. For an interesting map of the Chinese disputes, see as well the WTO website, www.wto.org/english/tratop_e/dispu_e/dispu_maps_e.htm?country_selected=CHN\&sense=e (consulted on 24 February 2012).

11. On China's accession to the WTO, see Leilla Choukroune and Jean-Pierre Cabestan, "China's accession to the WTO: a Turning Point?" and "Rule of Law Through Internationalisation, The Objective of the Reforms?," China Perspectives, no. 40, March-April 2002, pp. 4-6 and 7-20, and Leïla Choukroune, "China's Accession to the WTO and Legal Reform: Towards the Rule of Law via Internationalization without Democracy," in Pierre-Étienne Will and Mireille Delmas-Marty (eds.), China, Democracy and Law, Leiden, Brill, 2012.

12. We have recently seen an explosion of "academic" and/or official articles denouncing the unfairness of China's Protocol. See, for instance, Xiaohui Wu, "No Longer Outside, not yet Inside: Rethinking China's Membership into the WTO," Chinese Journal of International Law, vol. 10, 2011, pp. 227-270, www.chinesejil.oxfordjournals.org/content/10/2/227.full.pdf (consulted on 6 March 2012).

13. See our contribution to this special issue, Leilla Choukroune, "The Compromised Rule of Law by Internationalisation."

14. See China's Protocol of Accession, paragraph 9. 
Owned Enterprises (SOEs). (15) This, of course, is particularly tricky to implement in a "socialist market economy" in which the role of the state is still very pervasive. ${ }^{(16)}$ As we will see below, a number of recent disputes are precisely related to this ambiguous obligation and the similarly ambiguous Chinese economic and political position.

3. Obligations to eliminate export tariffs. In a departure from the WTO general rule allowing Members to levy taxes and charges on their exports, China is required to "eliminate(s) all taxes and charges applied to exports except for those specifically provided in the Annex 6 of the Protocol". (17)

4. Special obligations on foreign investment: Here again, the China Protocol departs from normal WTO disciplines. China, for instance - and this is very controversial today - may not make approval of foreign investment conditional upon the existence of domestic competitors or, more importantly, on any performance requirement including technology transfer or obligations to conduct research and development activities in China. ${ }^{(18)}$ Furthermore, foreign investors and foreign owned enterprises are entitled to National Treatment with respect to all their China activities.

5. Additional Transitional Review Mechanisms. A special transitional review mechanism (19) was established by the Chinese Protocol to review China's implementation every year during the first eight years after accession as well as on year ten. This special scrutiny regime was unique and additional to the usual trade policy reviews conducted for all WTO Members at regular intervals.

\section{WTO-minus provisions cover the following issues:}

1. Special anti-subsidy rules. China's Protocol permits an importing WTO Member to use non-market economy (NME) methodologies to calculate Chinese subsidies and possibly take measures against them. This is not subject to a time limit. There are also special rules for government subsidies to State Owned Enterprises (SOEs) that again departs from normal WTO rules. These include an additional ownership criterion when defining the specificity of government/public support. Under this criterion, subsidies granted to Chinese SOEs are considered to satisfy the requirement of specificity, thus making them actionable underWTO rules on subsidies. Curiously, China is not allowed to make use of a very interesting WTO provision allowing developing countries to provide subsidy to companies that are directly linked to a privatisation programme, even though one could imagine such a rule would promote the existing privatisation policy for Chinese SOEs. The lack of coherence in these measures makes application of China's Protocol of Accession more difficult.

2. Special anti-dumping rules. China's Protocol allows WTO Members to treat China as a non-market economy (NME) for 15 years, that is until 2016. (20) In WTO law, dumping is determined (21) when a product is exported at less than its "normal value" and causes or threatens to cause material injury to an industry of the importing country. As long as China is considered a NME, importing WTO Members can argue that the Chinese domestic prices cannot be used to assess the dumping margin and that generally higher priced equivalents in a third country should be used. As we will see in the below developments, tensions over the NME status of China seem set to continue, as there is no clear definition of a non-market economy in WTO law, and WTO Members applying antidumping measures have the right to determine whether the exporting country is or is not a market economy. China is likely to see itself as a victim of unfair anti-dumping methodologies, while the EU and US, as well as other emerging players, will more often target China for antidumping measures. It is equally easy to understand why China is pushing the EU and the US to obtain a market economy status that could clarify its situation and so the methodologies used to determine and assess dumping.

3. Special safeguards regime: The China Protocol contains a special set of safeguard provisions in addition to the existing WTO safeguard regime that can be invoked until 2013. WTO members can apply safeguards selectively against products of Chinese origin if they can show "market disruption" and "causality" with increased imports, an easier test than the normal injury test for safeguards under the WTO. Furthermore, an importing country does not even have to prove the "injury" and "causal link" if it argues that there is "trade diversion" as a result of another member's safeguards against China. One can clearly see the risks of this sort of spillover effects. There was also a special safeguard mechanism applicable to textile and clothing products of Chinese origin up to 2008. This allowed WTO members to impose quotas if they could show that imports of Chinese textile and clothing products caused "market disruption, threatening to impede the orderly development of trade in these products." This safeguard provided the basis for bilateral textile agreements between China and the EU and US in 2005. Of course, these rules were accepted by China during the course of the WTO accession negotiations, but as illustrated by the below disputes, they are extremely difficult to implement for both technical and political reasons.

\section{The Safeguards Battle}

The DS 399 (22) case deals with a transitional product-specific safeguard measure (the tyres measures) adopted under paragraph 16 of China's Protocol of Accession and applied on US imports from China of certain passenger vehicle and light truck tyres pursuant to Section 421 of the US Trade Act of 1974 (China Safeguards Investigations). (23)

15. See China's Protocol of Accession, paragraph 5 (1).

16. On the intertwined relations between the state and the economy, see for instance The Economist recent comparative study: The Economist, The Rise of State Capitalism, The Emerging World's New Model, January 21st-27th 2012.

17. See China's Protocol of Accession, paragraph 11 (3).

18. See China's Protocol of Accession, paragraph 7 (3).

19. See China's Protocol of Accession, paragraph 18.

20. See China's Protocol of Accession, paragraph 15.

21. See Article VI of GATT 1994 and the Anti-dumping Agreement.

22. See www.wto.org/english/tratop_e/dispu_e/cases_e/ds399_e.htm (consulted on 25 February 2012).

23. See United States International Trade Commission (USITC) at www.usitc.gov/press_room/us_safeguard.htm (consulted on 25 February 2012). Under Section 421 of the 1974 Trade Act, the USITC determines whether imports of a product from China "are being imported into the United States in such increased quantities or under such conditions as to cause or threaten to cause market disruption to the domestic producers of like or directly competitive products." If so, a remedy is proposed by the Commission. The Commission sends its report to the American President and the U.S. Trade Representative. The President makes the final remedy decision. 
Interestingly, this case highlights the interplay between public and private actors and the lobbying power of national interest groups at a time of "deindustrialisation" and economic crisis. On 20 April 2009 indeed, a petition was filed by the United Steel, Paper and Forestry, Rubber, Manufacturing, Energy, Allied Industrial and Service workers International Union (the USW) requesting the United States International Trade Commission (USITC) to determine that light truck tyres from China were being imported in such a way to cause or threaten to cause market disruption. On 24 April 2009 an investigation was instituted by the USITC and determined that there was indeed a market disruption as a result of rapidly increasing imports of quantities of Chinese tyres causing domestic injury to the domestic industry. A remedy was found and, as per the 1974 Trade Act procedure, a Presidential decision taking effect on 26 September 2009 allowed additional duties to be imposed on imports of tyres from China for a three-year period 35 percent ad valorem for the first year, 30 percent ad valorem for the second year and 25 percent ad valorem for the third year). In reaction to these measures, China made seven specific claims in relation to paragraph 16 (Transitional Product-Specific Safeguard Mechanism) of its Protocol of Accession and GATT 94: The US failed to evaluate whether imports from China are in "such increased quantities" and "increased rapidly" as required by 16.1 and 16.4 of the Protocol. (24)

The US Statute implementing the causation standard of Paragraph 16 in to US Law was inconsistent "as such" with Paragraphs 16.1 and 16.4 of the Protocol.

- The US failed to evaluate properly whether imports from China were a "Significant Cause" as required by the paragraph 16.1 and 16.4 of the Protocol.

- The US Statute implementing the causation standard of paragraph 16 into US law was inconsistent "as such" with paragraphs 16.1 and 16.4 of the Protocol.

- The US failed to evaluate if imports from China were a significant cause as required by paragraph 16.1 and 16.4 of the Protocol.

- The US imposed a transitional safeguard measure that went beyond the "extent necessary" and was thus inconsistent with paragraph 16.3 of the Protocol.

- The US imposed a three-year safeguard period that went beyond the "necessary" period of time and was hence inconsistent with paragraph 16.6 of the Protocol.

- The transitional safeguard measure was inconsistent with Article I:1 (Most-Favoured-Nation Treatment) of the GATT 94, as the US did not accord the same treatment to Chinese imports as it does to other countries imports

- The transitional safeguard measure is inconsistent with Article II:1 (b) (Schedules of Concessions) of the GATT 94 as the tariffs consist of unjustified modifications of US concessions on passenger vehicles and light truck tyres under the CATT 94.

Naturally, China asked the WTO Panel to recommend that the US promptly comply with its WTO obligations and so withdraw the challenged measure, while the US asked the Panel to reject China's claims in their entirety. After the panel rejected all of China claims under paragraph 16 of its Protocol of Accession and GATT 94 and concluded that the US did not fail to comply with its obligations, China appealed the decision. However, China did not appeal a number of findings by the Panel, specifically the following elements: the US measure did not exceed the extent and the period of time necessary to prevent or remedy the market disruption, and the US causation standard in Section 421 of the 1974 Trade Act was not inconsistent with the Section 16 of the Chinese Protocol of Accession.

In its reasoning, the WTO Appellate Body (AB) grasped the opportunity of this case to clarify the relationship between the Chinese Protocol of Accession and other WTO Agreements: within the meaning of the Article 31(1) and (2) of the Vienna Convention on the law of treaties, (25) the WTO Agreements serving as a contextual reference for the interpretation of the Protocol of Accession and in this case paragraph 16. In interpreting the meaning of the term "significant cause" included in paragraph 16, the AB also shed light on the rigorous character of the Chinese Protocol in comparison with other WTO safeguard-related measures. Interestingly as well, the AB rejected a quite ambitious argument from the Chinese side: China indeed tried to demonstrate that the Panel failed to conduct an "objective assessment of the matter" as required under the Article 11 of the DSU (Function of Panels). To do so, China attempted to show that the Panel failed to consider the totality of the evidence on the question of causation. Having considered all Chinese arguments, the $A B$ upheld the Panel findings.

This apparently technical and somehow limited case provides a particularly clear illustration of the subtle, yet demanding, drafting of the Chinese Protocol. Well protected against market disruptions caused by Chinese imports until 2013, the WTO Members will have to adjust their strategies and legal defences to the rapidly evolving new commercial done that will develop in a less rigorous environment.

\section{Non market economy, antidumping, and countervailing duties: The complicated equation}

\section{Unfair Trade}

Unfair trade can take many forms from the fixation of prices to monopolies and cartels, but under the WTO Agreements, one generally refers to the issues of dumping and subsidisation, two quite common practices considered, in the limits defined by the WTO, as unfair. As surprising as it may seem to the non-trade lawyer, dumping and subsidisation are not prohibited in WTO law. However, dumping is "condemned" if it causes an injury to the domestic industry, while in a more complex fashion, subsidies are either prohibited or may be challenged when they cause adverse effects to the interests of other members. (26) The dumping issue is covered by the Agree-

24. See Annex 2, paragraph 16 of China's Protocol of Accession.

25. Article 31 General rule of interpretation

1. A treaty shall be interpreted in good faith in accordance with the ordinary meaning to be given to the terms of the treaty in their context and in the light of its object and purpose.

2. The context for the purpose of the interpretation of a treaty shall comprise, in addition to the text, including its preamble and annexes: (a) any agreement relating to the treaty which was made between all the parties in connection with the conclusion of the treaty; $(b)$ any instrument which was made by one or more parties in connection with the conclusion of the treaty and accepted by the other parties as an instrument related to the treaty.

3. There shall be taken into account, together with the context: 12(a) any subsequent agreement between the parties regarding the interpretation of the treaty or the application of its provisions; (b) any subsequent practice in the application of the treaty which establishes the agreement of the parties regarding its interpretation; (c) any relevant rules of international law applicable in the relations between the parties.

4. A special meaning shall be given to a term if it is established that the parties so intended. Source: http://untreaty.un.org/ilc/texts/1_1.htm (consulted on 25 February 2012).

26. For a lucid introduction to these particularly complex and controversial issues, see Peter van den Bossche, The Law and Policy of the World Trade Organisation, supra note 6, pp. 507-605. 
ment on the Implementation of Article VI of the GATT 1994 known as the Antidumping Agreement (27) (AD), and the Subsidies question is framed by the Agreement on Subsidies and Countervailing Measures (SCM). (28)

The Chinese Protocol of Accession complicated an already detailed and complex picture. Indeed, paragraph 15 of the Protocol sets specific rules for price comparability in determining subsidies ${ }^{(29)}$ and dumping:

(a) In determining price comparability under Article VI of the GATT 1994 and the Anti-Dumping Agreement, the importing WTO Member shall use either Chinese prices or costs for the industry under investigation or a methodology that is not based on a strict comparison with domestic prices or costs in China based on the following rules: ${ }^{30}$

(i) If the producers under investigation can clearly show that market economy conditions prevail in the industry producing the like product with regard to the manufacture, production and sale of that product, the importing WTO Member shall use Chinese prices or costs for the industry under investigation in determining price comparability;

(ii) The importing WTO Member may use a methodology that is not based on a strict comparison with domestic prices or costs in China if the producers under investigation cannot clearly show that market economy conditions prevail in the industry producing the like product with regard to manufacture, production and sale of that product.

(b) In proceedings under Parts II, III and V of the SCM Agreement, when addressing subsidies described in Articles 14(a), 14(b), 14(c) and 14(d), relevant provisions of the SCM Agreement shall apply; however, if there are special difficulties in that application, the importing WTO Member may then use methodologies for identifying and measuring the subsidy benefit which take into account the possibility that prevailing terms and conditions in China may not always be available as appropriate benchmarks. In applying such methodologies, where practicable, the importing WTO Member should adjust such prevailing terms and conditions before considering the use of terms and conditions prevailing outside China.

As demonstrated by the above reproduced subparagraphs (a) and (b) of paragraph 15 of the Chinese Protocol, the methodologies applied to China depart from the general WTO methodologies used in anti-dumping and subsidy investigations. The main justification for this exceptional approach is based on the specificity of the Chinese "socialist market economy" in which the state is still very much prevalent through a number of possible interventions in the economy from special loans to subsidies and SOEs. This unusual and somehow vague approach is nevertheless framed by the need for importing WTO Members to notify "methodologies used" to the "Committee on Anti-Dumping Practices and the Committee on Subsidies and Countervailing Measures." Lastly, the provisions of subparagraph (a) shall be terminated "once China has established, under the national law of the importing WTO Member that it is a market economy (...) provided that the importing Member's national law contains market economy criteria as of the date of accession. In any event, the provisions of the subparagraph (a)(ii) shall expire 15 years after the date of accession." (31)

Two recent cases provide a very detailed illustration of the difficulty WTO Members are now facing in the interpretation and implementation of the anti-dumping and subsidies provisions.
In the first case (DS 379), (32) in 2007, the United States Department of Commerce (USDOC) reversed its policy and decided that its countervailing legislation would apply to the Chinese economy, which while still not a market economy has undergone sufficient economic reform as to enable the USDOC to identify and countervail subsidies granted by the Chinese Government. On 19 September 2008, in reaction to this quite surprising decision (in anti-dumping investigations the USDOC continues to treat China as a non-market economy), China requested consultations with the US with respect to definitive anti-dumping and countervailing duties imposed by Washington on imports of four products from China. In the second case (DS 397), ${ }^{33}$ on 31 July 2009, China requested consultations with the European Union regarding Article 9(5) of Council Regulation (EC) no. 384/96 of December 1995 dealing with protection against dumped imports from nonEU Members countries, as amended, and Council Regulation (EC) no. 91/2009 of 26 January 2009 imposing a definitive anti-dumping duty on imports of certain iron or steel fasteners originating from China. Here again, China challenged the complex EU methodology as applied to a nonmarket economy.

Beyond the technical considerations on anti-dumping and subsidies investigations methodologies applicable to a non-market economy, the panels and Appellate Body have touched upon, and to a certain extend clarified, a crucial concept, that of a "Public Body," hence further delimiting the contours of the state's intervention in international trade.

\section{Public Body}

In the US- Definitive Anti-Dumping and Countervailing Duties on Certain Products from China (DS 379), China in fact appealed the Panel's interpretation and application of Article 1.1(a)(1) of the SCM Agreement and challenged the Panel's finding that the term "public body" means "any entity controlled by a government." In the same perspective, China took issue with the Panel's interpretative approach and acted inconsistently with the DSU in its interpretation techniques and reliance on municipal law. To this we should add that the Chinese Protocol gives a particularly precise definition of the subsidies provided to SOEs. Paragraph 10 of the Chinese Protocol states the following:

1. China shall notify the WTO of any subsidy within the meaning of Article 1 of the Agreement on Subsidies and Countervailing Measures ("SCM Agreement"), granted or maintained in its territory, organized by specific product, including those subsidies defined in Article 3 of the SCM Agreement. The information provided should be as specific as possible, following the requirements of the questionnaire on subsidies as noted in Article 25 of the SCM Agreement.

27. See www.wto.org/english/docs_e/legal_e/19-adp_01_e.htm (consulted on 25 February 2012). 28. See www.wto.org/english/docs_e/legal_e/24-scm_01_e.htm (consulted on 25 February 2012).

29. On the arduous question of subsidies in the Chinese Protocol of accession, see Julia Ya Qin, "WTO Regulation of Subsidies to State-Owned Enterprises (SOEs): A Critical Appraisal of the China Accession Protocol," Journal of International Economic Law, Oxford, Oxford University Press, vol. 7, no. 4, 2004, pp. 863-919.

30. Highlighted in bold by the author.

31. China's Protocol of Accession, paragraph 15 (d). The paragraph is concluded with the following elements: "In addition, should China establish, pursuant to the national law of the importing WTO Member, that market economy conditions prevail in a particular industry or sector, the non-market economy provisions of subparagraph (a) shall no longer apply to that industry or sector."

32. See www.wto.org/english/tratop_e/dispu_e/cases_e/ds379_e.htm (consulted on 25 February 2012).

33. See www.wto.org/english/tratop_e/dispu_e/cases_e/ds397_e.htm (consulted on 25 February 2012). 
2. For purposes of applying Articles 1.2 and 2 of the SCM Agreement, subsidies provided to state-owned enterprises will be viewed as specific if, inter alia, state-owned enterprises are the predominant recipients of such subsidies or state-owned enterprises receive disproportionately large amounts of such subsidies. ${ }^{(34)}$

3. China shall eliminate all subsidy programmes falling within the scope of Article 3 of the SCM Agreement upon accession.

And this is precisely the specificity of the subsidies granted to Chinese SOEs that allows WTO Members to challenge them. Indeed, WTO rules on subsidies do not apply to all "financial contributions by a government that confer a benefit," that is to all subsidies, but only to specific ones. ${ }^{(35)}$

Departing from the panel's findings, the Appellate Body considered the meaning of the term "public body" in accordance with Article 31 (general rules if interpretation) of the Vienna Convention on the law of treaties, and while it found that the concept of "public body" shared a number of attributes with the concept of "government," it found, as well, that the object and purpose of the SCM Agreement do not favour either a broad or a narrow interpretation of this term. Taking also into consideration the International Law Commission's Articles on Responsibility of States for Internationally Wrongful Acts, the AB concluded that the concept of "public body" is an entity that possesses, exercises, or is vested with governmental authority. Yet, the $A B$ made clear that this definition may vary from state to state and case to case. Based on its interpretation of the term "public body," the AB reversed the Panel's finding that the term public body means "any entity controlled by a government." The AB was then able to complete its analysis with regard to the Chinese SOEs in the four companies at issue, which were producers of steel, rubber, and petrochemical components sold to the investigated companies or to trading companies. Indeed, the US administration had based its analysis of the "public body" concept on the majority state ownership of the companies. The AB considered in this regard that evidence of government ownership is not in itself evidence of control of an entity by the government and cannot as such serve as a proof for establishing that the entity is vested with the needed authority to perform a government function and so is a "public body." On the contrary, the AB found that state-owned commercial banks (SOCBs) were public bodies under Article 1.1(a)(1) of the SCM Agreement as other evidences relating to the Chinese government role in the banking sector could be considered.

As sophisticated as it is, this demonstration and the many $A B$ decisions on the methodological intricacies of the determination of dumping and subsidisation may soon be challenged in other $A D$ and countervailing cases, not only by the EU or the US, but also by China itself. In a fascinating parallel reaction indeed, China is also imposing AD measures on other members products, already leading to a number of new cases brought by the US in the past two years. In September 2010, the US initiated a WTO case challenging the anti-dumping and countervailing duties China imposed on imports of "Grain Oriented Flat Rolled Electrical Steel" (DS 414). (36) In September 2011, the US brought another WTO claim challenging the antidumping and countervailing duties China imposed on imports of certain American chicken products known as "broiler" products (DS 427). ${ }^{(37,38)}$ The issue at stake is mainly that of transparency. Upon accession to the WTO, China has issued a large number of new rules bringing its former regulations into conformity with the WTO regime, but Beijing still needs to improve its transparency-related requirements and to better notification of its antidumping (AD) related measures and reforms.

\section{Restrictions on imports and exports}

Another fundamental question is progressively emerging from the recently concluded disputes. Although fragmented in quite different cases, the concept of state restrictions on imports and exports for economic, but also political and societal issues is now evidenced by several decisions. We will pay particular attention - although too rapidly due to the length limitations of this article - to two disputes: China Measures Affecting Trading Rights and Distribution Services for Certain Publications and Audio-visual Entertainment Products (DS 363), (39) and China Measure Related to the Exportation of Various Raw Materials (DS 394/DS 395/ DS 398). ${ }^{(40)}$

In the Audio-visual Entertainment Products case, the dispute dealt with a complaint brought by the US with respect to various measures relating to the importation into and distribution within China of reading materials, audio-visual home entertainment products, sound recordings, and films for release in movie theatres. ${ }^{(41)}$ In reaction to the American claims, China argued in favour of the specificity of cultural goods and the need to review their content in the view of possible impact on public morals. The disguised Chinese censorship was however found inconsistent with China's trading rights commitments contained in paragraph 5 (1) of the Protocol of Accession and paragraphs 83(d) and 84 (a) and (b) of the Report of the Working Party on China's accession. Under these provisions, all Chinese enterprises, as well as foreign enterprises and individuals, are to be granted, within three years of accession, the right to import and export all goods in a non-discretionary manner. Not to mention that the Chinese restrictions were inconsistent with China's schedules of commitments on market access (a list of open services) or national treatment under Articles XVI and XVII of the General Agreement on Trade in Services (GATS). Moreover, in a brilliant technical demonstration, the Appellate Body upheld the Panel findings that China's use of Article XX (a) of the GATT 94 (General Exceptions) was not convincing. ${ }^{(42)}$ Beijing indeed tried to demonstrate that the "public morals" exception of GATT 94 Article XX (a) could justify its measures, but it failed to prove the "necessary" character of such exception.

In the Raw Materials dispute, cases were brought against China in relation to the four types of export restraint it imposed on the exports of various raw materials (bauxite, coke, fluorspar, magnesium, manganese, silicon metal, yellow phosphorus, and zinc). Having in mind the unquenched thirst of China for commodities and natural resources, this dispute resounds in a

34. Highlighted in bold by the author.

35. Cf. Article 1.2 of the SCM Agreement: "A subsidy as defined in paragraph 1 shall be subject to the provisions of Part II or shall be subject to the provisions of part III or V only if such a subsidy is specific in accordance with provisions of article 2."

36. See www.wto.org/english/tratop_e/dispu_e/cases_e/ds414_e.htm (consulted on 6 March 2012).

37. See www.wto.org/english/tratop_e/dispu_e/cases_e/ds427_e.htm (consulted on 6 March 2012).

38. See as well the last USTR evaluation of China's WTO Commitments implementation. USTR, 2011 Report to Congress on China's WTO Compliance.

39. See www.wto.org/english/tratop_e/dispu_e/cases_e/ds363_e.htm (consulted on 6 March 2012).

40. See www.wto.org/english/tratop_e/dispu_e/cases_e/ds398_e.htm (consulted on 6 March 2012).

41. See the articles of Rogier Creemers and Bryan Mercurio in this special issue.

42. The Article XX (a) of GATT 94 reads as follow: "Subject to the requirement that such measures are not applied in a manner which would constitute a means of arbitrary or unjustifiable discrimination between countries where the same conditions prevail, or a disguised restriction on international trade, nothing in this Agreement shall be construed to prevent the adoption or enforcement by any contracting party of measures: (a) necessary to protect public morals; [...]." 
peculiar way. The Complainants argued that the use of export restraints creates scarcity and causes higher prices of raw materials in global markets as well as providing China's domestic industry with an unfair advantage by way of sufficient supply and thus cheaper prices. Upon accession to the WTO, China agreed, as we have seen, to eliminate all exports taxes and charges and all export quotas. But here again, China tried to use the general trade exceptions contained in GATT 94 Article XX (b) (exception "necessary to protect human, animal or plant life or health") and (g) (exception "relating to the conservation of exhaustible natural resources if such measures are made effective in conjunction with restrictions on domestic production or consumption") to support its restrictive measures. The Appellate Body nevertheless upheld the Panel's finding that there is no basis in China's Accession Protocol to allow the application of Article XX of the GATT 1994 to China's obligations under Paragraph 11.3 of the Accession Protocol (Taxes and Charges levied on Exports and Imports) and found that China cannot have recourse to Article XX to justify a breach of its obligation to eliminate export duties.

While similar cases are likely to appear in the near future, these disputes are quite revealing of China's internal needs and struggles between the imperative of export-oriented growth and the political strategic choices Beijing's leaders have made to build up and consolidate their vision of a developed yet not autonomous society.

\section{Conclusion}

Ten years ago, a dispute between China and Japan over Japanese safeguard measures against three agricultural products from China gave an early indication of Beijing's determination to put its new legal arsenal to good use. China was not yet a member of WTO, but both parties frequently referred to the WTO agreements in their legal arguments. A few months later, in 2002, China grabbed the attention of trade lawyers with its provisional safeguard measures with respect to certain American steel products. These came less than six months after China adopted legislation on safeguards, causing some experts to qualify Beijing's attitude as "aggressive legalism."

A wise observer and fast learner in global trade, China is now able to put its recently acquired knowledge into practice and will undoubtedly bring new claims against its main trading partners while these same partners will follow the pace of global trade and more often target China. Interestingly, these novel trade disputes may not be fought by the EU or the US, but rather by emerging economies such as Brazil or India. With the recent imposition of a 30 percentage point tax increase on cars with less than 65 percent local content, the Brazilian government firmly reacted to the significant imports of Chinese cars and the risk of seeing the country "de-industrialise." Following Tata Motors' announcements, other foreign cars companies may decide to build up car factories in Brazil, hence avoiding high taxes, but this may also result in a major WTO dispute as Brazilian as well as Indian - Industrialists seem to distinguish between Chinese and other trade competitors. Having emerging or developing countries fighting against each other at the WTO is not something new. India, for instance, has brought a number of complaints against Brazil, Argentina, and South Africa, but something else is at stake today. Many of these emerging trade champions are, to a very large (China) or much smaller extent (Brazil), "State Capitalists." Ambiguous market economies or economies in transition, they play with different rules than those ideally imagined for a free trade world, and skilfully select legal tools available in the WTO Agreement that could better protect their syncretic economic model, hence contributing to the creation of an hybrid system and a possible redefinition of the WTO's values and role.

Is this something to worry about or, rather an opportunity for clarification of the rules of the game? One can indeed wonder wether free trade has ever existed when the EU or the US keep fighting over the unacceptable character of their respective highly subsidised industries or agricultures. This eruption of new players on the commercial scene may lift the veil of hypocrisy that reigns over an idealised model of international trade that is not always respected by its main proponents. 


\section{As complainant: 8 cases}

DS252 United States — Definitive Safeguard Measures on Imports of Certain Steel Products (Panel Report circulated on 11 July 2003 , Appellate Body Report circulated on 10 November 2003)

DS368 United States - Preliminary Anti-Dumping and Countervailing Duty Determinations on Coated Free Sheet Paper from China (Request for Consultations 14 September 2007)

DS379 United States - Definitive Anti-Dumping and Countervailing Duties on Certain Products from China (Panel Report circulated on 22 October 2010, Appellate Body Report circulated on 11 March 2011)

DS392 United States - Certain Measures Affecting Imports of Poultry from China (Panel report circulated on 29 September 2010)

DS397 European Communities — Definitive Anti-Dumping Measures on Certain Iron or Steel Fasteners from China (Panel Report circulated on 3 December 2010, Appellate Body Report circulate on 15 July 2011)

DS399 United States — Measures Affecting Imports of Certain Passenger Vehicle and Light Truck Tyres from China (Panel Report circulated on 13 December 2010, Appellate Body Report circulated on 5 September 2011)

DS405 European Union - Anti-Dumping Measures on Certain Footwear from China (Panel Report 28 October 2011)

DS422 United States - Anti-Dumping Measures on Shrimp and Diamond Sawblades from China

\section{As respondent: 23 cases}

DS309 China - Value-Added Tax on Integrated Circuits (Mutually Agreed Solution 6 October 2005)

DS339 China - Measures Affecting Imports of Automobile Parts (Panel Report circulated on 18 July 2008, Appellate Body Report circulated on 15 December 2008)

DS340 China - Measures Affecting Imports of Automobile Parts (Panel Report circulated on 18 July 2008, Appellate Body Report circulated on 15 December 2008)

DS342 China - Measures Affecting Imports of Automobile Parts

DS358 China - Certain Measures Granting Refunds, Reductions or Exemptions from Taxes and Other Payments (Agreement reached in December 2007)

DS359 China - Certain Measures Granting Refunds, Reductions or Exemptions from Taxes and Other Payments (Agreement reached on February 2008)

DS362 China - Measures Affecting the Protection and Enforcement of Intellectual Property Rights (Panel Report circulated on 26 January 2009)

DS363 China - Measures Affecting Trading Rights and Distribution Services for Certain Publications and Audiovisual Entertainment Products (Panel Report circulated on 12 August 2009, Appellate Body Report circulated 21 December 2009)

DS372 China - Measures Affecting Financial Information Services and Foreign Financial Information Suppliers (complainant EU) (Agreement reached on December 2008)

DS373 China - Measures Affecting Financial Information Services and Foreign Financial Information Suppliers (complainant US) (Agreement reached on December 2008)

DS378 China - Measures Affecting Financial Information Services and Foreign Financial Information Suppliers (complainant Canada) (Agreement reached on December 2008)

DS387 China - Grants, Loans and Other Incentives (complainant US)

DS388 China - Grants, Loans and Other Incentives (complainant Mexico)

DS390 China - Grants, Loans and Other Incentives (complainant Guatemala)

DS394 China - Measures Related to the Exportation of Various Raw Materials (Complainant US) (Panel Report circulated on 5 July 2011, Appellate Body Report circulated on 30 January 2012)

DS395 China - Measures Related to the Exportation of Various Raw Materials (complainant UE) (Panel Report circulated 5 July 2011, Appellate Body Report circulated 30 January 2012)

DS398 China - Measures Related to the Exportation of Various Raw Materials (complainant Mexico) (Panel Report circulated on 5 July 2011 Appellate, Body Report circulated on 30 January 2012)

DS407 China - Provisional Anti-Dumping Duties on Certain Iron and Steel Fasteners from the European Union

DS413 China - Certain Measures Affecting Electronic Payment Services (Panel established in March 2011)

DS414 China - Countervailing and Anti-Dumping Duties on Grain Oriented Flat-rolled Electrical Steel from the United States

DS419 China - Measures concerning wind power equipment (complainant US)

DS425 China - Definitive Anti-Dumping Duties on X-Ray Security Inspection Equipment from the European Union

DS427 China - Anti-Dumping and Countervailing Duty Measures on Broiler Products from the United States

Source: www.wto.org/english/thewto_e/countries_e/china_e.htm (consulted on 25 February 2012). 


\section{Transitional Product-Specific Safeguard Mechanism}

1. In cases where products of Chinese origin are being imported into the territory of any WTO Member in such increased quantities or under such conditions as to cause or threaten to cause market disruption to the domestic producers of like or directly competitive products, the WTO Member so affected may request consultations with China with a view to seeking a mutually satisfactory solution, including whether the affected WTO Member should pursue application of a measure under the Agreement on Safeguards. Any such request shall be notified immediately to the Committee on Safeguards.

2. If, in the course of these bilateral consultations, it is agreed that imports of Chinese origin are such a cause and that action is necessary, China shall take such action as to prevent or remedy the market disruption. Any such action shall be notified immediately to the Committee on Safeguards.

3. If consultations do not lead to an agreement between China and the WTO Member concerned within 60 days of the receipt of a request for consultations, the WTO Member affected shall be free, in respect of such products, to withdraw concessions or otherwise to limit imports only to the extent necessary to prevent or remedy such market disruption. Any such action shall be notified immediately to the Committee on Safeguards.

4. Market disruption shall exist whenever imports of an article, like or directly competitive with an article produced by the domestic industry, are increasing rapidly, either absolutely or relatively, so as to be a significant cause of material injury, or threat of material injury to the domestic industry. In determining if market disruption exists, the affected WTO Member shall consider objective factors, including the volume of imports, the effect of imports on prices for like or directly competitive articles, and the effect of such imports on the domestic industry producing like or directly competitive products.

5. Prior to application of a measure pursuant to paragraph 3, the WTO Member taking such action shall provide reasonable public notice to all interested parties and provide adequate opportunity for importers, exporters and other interested parties to submit their views and evidence on the appropriateness of the proposed measure and whether it would be in the public interest. The WTO Member shall provide written notice of the decision to apply a measure, including the reasons for such measure and its scope and duration.

6. AWTO Member shall apply a measure pursuant to this Section only for such period of time as may be necessary to prevent or remedy the market disruption. If a measure is taken as a result of a relative increase in the level of imports, China has the right to suspend the application of substantially equivalent concessions or obligations under the GATT 1994 to the trade of the WTO Member applying the measure, if such measure remains in effect more than two years. However, if a measure is taken as a result of an absolute increase in imports, China has a right to suspend the application of substantially equivalent concessions or obligations under the GATT 1994 to the trade of the WTO Member applying the measure, if such measure remains in effect more than three years. Any such action by China shall be notified immediately to the Committee on Safeguards.

7. In critical circumstances, where delay would cause damage which it would be difficult to repair, the WTO Member so affected may take a provisional safeguard measure pursuant to a preliminary determination that imports have caused or threatened to cause market disruption. In this case, notification of the measures taken to the Committee on Safeguards and a request for bilateral consultations shall be effected immediately thereafter. The duration of the provisional measure shall not exceed 200 days during which the pertinent requirements of paragraphs 1, 2 and 5 shall be met. The duration of any provisional measure shall be counted toward the period provided for under paragraph 6.

8. If a WTO Member considers that an action taken under paragraphs 2, 3 or 7 causes or threatens to cause significant diversions of trade into its market, it may request consultations with China and/or the WTO Member concerned. Such consultations shall be held within 30 days after the request is notified to the Committee on Safeguards. If such consultations fail to lead to an agreement between China and the WTO Member or Members concerned within 60 days after the notification, the requesting WTO Member shall be free, in respect of such product, to withdraw concessions accorded to or otherwise limit imports from China, to the extent necessary to prevent or remedy such diversions. Such action shall be notified immediately to the Committee on Safeguards.

9. Application of this Section shall be terminated 12 years after the date of accession.

* Document retrieved from WTO website: http://docsonline.wto.org/imrd/directdoc.asp?DDFDocuments/t/WT/L/432.doc (consulted on 23 March 2012). 